\title{
Status of Infection Control in Jeju-area General Hospitals
}

\author{
Moo Sang Chong ${ }^{1}$ and Kyutaeg Lee ${ }^{2}$ \\ ${ }^{1}$ Department of Clinical Pathology, Cheju Halla University, Jeju 63092, Korea \\ ${ }^{2}$ Department of Laboratory Medicine, Cheju Halla General Hospital, Jeju 63127, Korea
}

\section{제주특별자치도 종합병원의 감염관리 현황}

\author{
정무상 ${ }^{1}$, 이규택 ${ }^{2}$ \\ ${ }^{1}$ 제주한라대학교 임상병리과, ${ }^{2}$ 제주한라병원 진단검사의학과
}

\begin{abstract}
The aim of this study was to examine and analyze the infection management status of Jeju-area general hospitals, and in order to convey the importance of infection management, and to determine role plans of medical technologists as infection management staff, the infection management status was examined through surveys targeting 7 general hospitals located in Jeju Special Self-Governing Province. The infection management of Jeju-area medical institutions showed excellence in that all institutions operated an infection management room, there was dedicated manpower, and hospital infection management guidelines were established and executed. However most institutions were operating their infection management room with only 1 nurse, reporting many difficulties in securing dedicated manpower, microbe-related culture deciphering, frequency of multiple-resistance bacteria, infection statistics, and details on microbe testing. Accordingly, it is believed that the medical technologist who can perform the practical tasks of infection management has sufficient qualification and experience in infection management as per the medical law enforcement regulations, and in operation of an infection management room. If medical technologists (infection control microbiological technologist) with expert knowledge on microbes and infection control nurses can execute the tasks as dedicated personnel, the operation of the infection management room will be more advanced. In addition, for proper infection management in the future, the introduction of a medical system specialized in infection management and full support for infection management of vulnerable small/medium hospitals in addition to general hospitals across the country is considered important.
\end{abstract}

Keywords: Healthcare-associated infection, Hospital infection control, Infection control, General hospital

\footnotetext{
This is an Open Access article distributed under the terms of the Creative Commons Attribution Non-Commercial License (http://creativecommons.org/licenses/by-nc/4.0) which permits unrestricted non-commercial use, distribution, and reproduction in any medium, provided the original work is properly cited.

Copyright (C 2016 The Korean Society for Clinical Laboratory Science. All rights reserved.
}

Corresponding author: Moo Sang Chong Department of Clinical Pathology, Cheju Halla University Halla University, 38, Halladaehak-ro, Jeju 63092, Korea Tel: 82-64-741-6732 Fax: 82-64-741-6729 E-mail: chong@chu.ac.kr

Received: March 25, 2016 Revised $1^{\text {st: }}$ : April 18, 2016 Revised 2 ${ }^{\text {nd }}$ : April 28, 2016 Revised 3 ${ }^{\text {rd: }}$ April 30, 2016 Accepted: April 30, 2016

\section{서 론}

최근 국내에서는 메르스 사태로 인한 재해가 국민을 한동안 공 포 속에 빠뜨리기도 했다. 또한 메르스에 이어 지카 바이러스까지 전 세계적으로 바이러스 공포가 계속되고 있는 상황이 지속되어 병 원감염관리의 중요성이 더욱 대두되고 있다. 의료관련감염 (healthcare-associated infection)은 입원 시에 존재하지 않았고,
잠복기도 아닌 상태에서 의료기관에 입원 중에 발병한 감염으로 흔 히 입원 48시간 후에 발생된 감염을 말한다[1]. 의료관련감염은 경 제적, 윤리적, 사회적 측면 등 많은 부분에서 문제점이 야기되고 있 으며, 법정 감염병 중 지정 감염병에 속하는 의료관련감염병인 methicillin-resistant Staphylococcus aureus (MRSA), vancomycin-resistant Staphylococcus aureus (VRSA), vancomycin-resistant Enterococci (VRE), multidrug-resistant 
Pseudomonas aeruginosa (MRPA), multidrug-resistant Acinetobacter baumannii (MRAB), carbapenem-resistant Enterobacteriaceae (CRE)에 의한 감염의 증가와 관련되어 병원 감염관리의 중요성이 증대되고 있다[2]. 또한 현대의 의료 환경은 새로운 항생제가 개발되고, 각종 소독제가 사용되며 장갑과 가운 등 보호장구의 착용이 강화되었음에도 불구하고 항암 요법의 발달, 면역억제제 사용 등으로 인한 면역 기능 저하 환자의 증가, 침습적 시술의 보편화, 항균제 내성 균주의 증가 등으로 인해 병원감염의 중요성은 지속적으로 증가하고 있다[3]. 대표적인 의료관련감염은 요로감염, 폐렴, 수술 부위 감염, 혈관 내 카테터 관련 감염 등이 있 는데 메르스는 특수한 상황이기는 하지만 의료관련감염 범주에 넣 는다면 폐렴 범주 안에 들어갈 수 있다[4]. 메르스 감염의 경우 환자 들이 여러 의료기관들을 이동하여 진료를 받은 부분이 여러 의료기 관에서 다수의 감염자를 나오게 한 원인이 되었다. 국민들이 대형 병원 선호는 동네 병 - 의원에 비해서 대형병원의 의료의 질이 더 좋 다는 인식 때문이고, 대형병원에 비해서 병 - 의원이 환자를 지속적 으로 관리, 교육하고 만성질환자에 대한 지속적인 관리를 할 수 있 음에도 불구하고 의료관련감염 서비스에 대해서는 보상을 해주지 않기 때문에 병 - 의원이 대형병원과 경쟁을 하게 되어 국민들이 기 피하고 있는 실정이다[5].

국내 감염관리 전담인력은 1991년 서울대학교병원에 최초의 전담 감염관리간호사(Infection Control Nurse, ICN)가 배치된 이 후 감염관리간호사들이 병원감염관리 활동의 주체로서 병원감염 으로부터 환자와 직원을 보호하는데 선두적인 역할을 담당하여 왔 으며[6], 이후 2003년 개정된 의료법에서 300 병상 이상 종합병원 에는 감염대책위원회와 감염관리전문 인력을 두어 감염관리 프로 그램을 운영하도록 규정하고 있어, 대부분의 종합병원에서 전담 또 는 겸직 감염관리간호사를 채용하고 있다[7]. 현재 개정된 의료법 시행규칙에는 '병원(병상이 200개 이상인 경우만 해당한다) 및 종 합병원으로서 중환자실을 운영하는 의료기관의 장은 병원감염 예 방을 위하여 감염관리위원회와 감염관리실을 설치 · 운영하여야 한다'라고 규정 되어 있으며, 감염관리실에는 '감염 관리에 경험과 지식이 있는 의사, 감염 관리에 경험과 지식이 있는 간호사, 감염 관 리에 경험과 지식이 있는 사람으로서 해당 의료기관의 장이 인정하 는 사람을 각각 1 명 이상 두어야 한다'라고 규정되어 있다. 보건복 지부는 병원 감염관리실 설치 대상을 단계적으로 확대하고 감염관 리 인력을 확충하겠다고 밝힌바 있으며 이후 병상 수에 비례해 전 담 실무인력과 감염관리 전문의를 비치하도록 하고 중장기적으로 는 모든 병원급 의료기관에 감염관리업무를 전담 또는 겸임하는 인 력을 지정하도록 할 예정이다.

병원환경관리에서 미생물 검사실의 역할은 크다고 볼 수 있다.
의료관련감염 및 주요 내성 세균의 감시, 원내 집단감염 발생에 대 한 역학조사, 다제내성균의 보균자감시 등 감염관리에 중요한 역할 을 수행하고 있으며 환경관리를 위한 감시배양도 시행하고 있다. 유행이 발생했을 때 원인을 찾기 위해 역학조사의 한 부분으로 공 기, 물, 환경표면에 대한 정기적인 미생물 검사를 시행하거나, 오염 된 표면의 오염 정도와 청결도를 평가하기 위해 미생물 검사를 시 행하여야 한다[8]. 현재 의료 관련 감염 중 한 가지 이상의 항생제에 내성을 가진 미생물로 정의되는 다제내성균의 발병률은 전 세계적 으로 급격히 증가하고 있다[9]. 그 중, MRSA와 VRE는 지속적으로 증가되고 있다. 2013 2014년 전국병원감염감시체계의 결과에 의하면, 중환자실에서 분리되는 MRSA는 $87.6 \%$ 로 이미 허용 최대 치를 넘었고 VRE는 $49.3 \%$ 로 지속적으로 높은 상태로 보고되고 있 다[10]. 특히, 중환자실 환자들의 경우 말초 및 중심정맥도관과 같 은 침습적 기구들에 의해 피부통합성을 유지하기 어렵고, 면역억제 제와 같은 약제의 사용과 당뇨와 같은 기저질환으로 인해 정상적인 숙주방어체계가 약화되어 감염성 합병증에 취약한 상태이기 때문 에 감염 위험성은 더욱 높게 나타나고 있다[11]. 이러한 다제내성균 에 의한 의료 관련 감염은 항생제의 종류를 제한하는 것은 물론 사 망률, 내원 일수의 연장과 의료비의 상승과 같은 많은 문제를 야기 하고 있으며, 미국의 경우, 외과적 상처에 있는 MRSA는 메치실린 감수성 황색 포도상 구균(Methicillin-Susceptible Staphylococcus Aureus, MSSA)과 비교했을 때 수술 후 90일내에 사망위험이 3.4 배, 감염이 없는 상태와 비교했을 때는 11.4 배 높게 보고되고 있다 [12]. 이러한 다제내성균이 발생했을 경우 정보를 보다 빠르게 감염 관리실에 제공하여 감염관리 대처방안을 수립해야만 한다. 다제내 성균의 진단검사를 비롯한 미생물 검사는 임상병리사의 역할이며, 항생제 내성률 통계를 비롯한 다약제 내성균 발생현황 및 통계를 제공할 수 있다.

최근 들어 종합병원뿐만 아니라 200 병상 미만의 중 - 소형 병원 의 감염관리 현황 파악과 체계적인 감염관리 활동이 제안되고 있는 실정이며, 의료관련감염관리 활동이 반드시 필요하므로 이들을 대 상으로 감염관리 실태를 조사 하는 것은 국내 감염관리 발전에 기 여하는 바가 매우 크다고 하겠다[13]. 이에 본 연구는 제주지역 종 합병원 감염관리 현황을 조사하여, 병원감염관리 실태와 문제점을 파악하고자 하였으며 감염관리의 중요성을 인식시키고 감염관리 실무자로서 임상병리사(감염관리임상병리사; Infection Control Medical Technologist, ICMT; Infection Control Microbiological Technologist, ICMT)의 역할 방안을 모색하는데 기초자료를 제시 하고자 한다. 


\section{재료 및 방법}

\section{1. 재료}

2015년 9월부터 2015년 12월까지 제주특별자치도 제주시와 서귀포시에 위치한 종합병원 7개 기관을 대상으로 감염관리 현황 을 설문지를 통하여 조사하였다. 설문지는 각 대상 종합병원의 감 염관리실에 직접 방문하여 배부하거나 지인을 통해 배부하였다.

\section{2. 방법}

제주특별자치도 종합병원의 감염관리 현황을 조사하고자 총 20 문항의 설문지를 작성하였다. 설문지는 기본적인 의료기관 현황, 의료기관의 감염관리지침, 임상병리사의 감염관리 역할 등 세 부분 으로 나누어 총 20 문항에 대한 설문을 조사하였다. 설문지의 내용 은 감염관리실 현황과 감염관리실에서 실시하여야 할 내용으로 원 내감염의 발생빈도가 높으면서도 중요한 사항 중심으로 작성하였 다. 기본적인 의료기관 현황 부분에서는 의료기관의 병상 수, 중환 자실의 병상 수, 감염관리실의 설립연도, 감염관리실의 구성인원, 감염관리실의 회의 빈도, 감염관리실에 배치된 인력 수와 인력의 직종, 감염관리실의 업무 인수인계, 인수인계 내용에 대하여 9문항 으로 제주지역 종합병원의 규모 및 감염관리실의 기본적인 현황을 조사하였다.

의료기관의 감염관리 부분에서는 전담인력의 감염관리 교육 빈 도, 감염관리지침(규정)의 유무, 감염관리지침(규정)의 수행도, 감 염관리실에서 감염감시 활동 등 6문항으로 실제적인 감염관리실 의 업무 현황 및 교육 빈도를 조사하였다. 임상병리사의 감염관리 역할 부분에서는 메티실린내성 황색포도알균(MRSA), 반코마이신 내성 황색포도알균(VRSA), 반코마이신내성 장알균(VRE), 다제내 성 녹농균(MRPA), 다제내성 아시네토바우마니균(MRAB), 카바페 넴내성 장내세균속균종(CRE) 등의 다제내성균주에 대한 감염관리 현황, 감염관리실과 미생물검사실 임상병리사와의 상호 협조정도 및 협조내용, 검사업무의 흐름에 대한 부분에서 임상병리사 역할 등 5 문항으로 설문조사 하였다. 연구의 참여여부는 대상자의 자율 적인 의지로 결정하며 연구목적 이외에는 결코 사용하지 않을 것임 을 제시하여 서면동의를 구하였다. 제주특별자치도에 위치한 종합 병원 7개 의료기관 감염관리실 전담자에 설문을 의뢰하였고 7 개 의료기관 모두 설문에 응답하여 설문지 회수율은 $100.0 \%$ 였다. 수 집된 자료는 빈도와 백분율로 자료를 분석하였다.

\section{결 과}

\section{1. 의료기관 현황}

의료법 시행규칙 제 43 조 감염관리위원회 및 감염관리실 설치 등에 관한 법률을 보면 “병원(병상이 200개 이상인 경우만 해당한 다) 및 종합병원으로서 중환자실을 운영하는 의료기관의 장은 병원 감염 예방을 위하여 감염관리위원회와 감염관리실을 설치 · 운영 하여야 한다"라고 규정되어 있다. 제주특별자치도에 위치한 종합 병원은 7 개 기관이며 제주시에 6개 기관 서귀포시에 1개 기관이 위 치해 있으며 500 병상 이상인 의료기관은 2 개 기관 $(28.6 \%), 300$ 399 병상은 1 개 기관(14.3\%), 200 299 병상은 4개 기관(57.1\%) 이었으며 중환자실의 병상 수는 40 병상 이상인 의료기관은 2 개 기 관(28.6\%), 10 19 병상은 5개 기관(71.4\%)으로 조사되었다. 7 개 의료기관 모두 감염관리실을 배치하고 있으며 감염관리실 설치 년 도는 2000년 이전이 1개 기관(14.3\%), 2001 2005년은 2개 기관 (28.6\%), 2006 2010년은 3개 기관(42.9\%), 2011 2015년은 1 개 기관(14.3\%)으로 나타났다. 감염관리실의 구성인원은 감염관 리 의사를 제외하고 감염관리실 인원이 3 명인 의료기관은 1 개 기 관(14.3\%), 1 명인 의료기관은 6 개 기관(85.7\%)으로 나타났으며, 감염관리실에 배치된 인력의 직종은 7 개 의료기관 9명 모두 간호 사로 조사되었으며 그 중 1명은 표본감시인력으로 조사되었다. 감 염관리실에 근무기간은 5년 이상이 1개 기관(14.3\%), 2 3년이 2 개 기관(28.6\%), 1 년 미만이 4 개 기관(57.1\%)으로 나타났다. 감염 관리실에서의 인수인계는 6 개 기관(85.7\%)이 선임자로부터 인수 인계를 받았으며, 1 개 기관(14.3\%)은 인수인계 없이 근무 한 것으 로 나타났다(Table 1).

\section{2. 의료기관의 감염관리}

의료기관의 감염관리실의 역할은 감염감시 업무(병동에서 일어 나는 감염질환 발생의 확인, 원내 환경의 오염상황이나 보균자의 파악, 병원 역학 정보의 파악)와 상담에 관한 업무(감염예방 관리에 대한 상담업무, 감염관리 지침서 - 가이드라인의 작성, 원내에서의 감염관리 조치 • 예방조치의 평가 및 지도, 홍보 및 교육, 병원 내 각 과와의 협력, 타 시설 - 지역 의료기관과의 감염관리 네크워크 구 축, 환자와 가족, 지역 주민 등에 대한 반응) 등의 업무를 수행해야 한다.

제주지역 의료기관에서의 전담인력의 외부학회 등에서의 감염 관리 교육빈도는 1년에 4번 이상이 1개 기관(14.3\%), 3 4번이 5 개 기관(71.4\%), 2 3번이 1개 기관(14.3\%)으로 조사되었으며, 직 원대상 자체 의료기관의 교육은 1 년에 4 번 이상이 2 개 기관 $(28.6 \%), 3 \sim 4$ 번이 2개 기관(28.6\%), 2 3번이 2개 기관(28.6\%), 
Table 1. General infection management activity status of Jeju-area medical institution

\begin{tabular}{|c|c|c|}
\hline Characteristics & Categories & n $(\%)$ \\
\hline \multirow[t]{3}{*}{ Number of beds in medical institutions } & $>500$ & $2(28.6)$ \\
\hline & $300 \sim 399$ & $1(14.3)$ \\
\hline & $200 \sim 299$ & $4(57.1)$ \\
\hline \multirow[t]{2}{*}{ Number of beds in ICU of medical institutions } & $>40$ & $2(28.6)$ \\
\hline & $10 \sim 19$ & $5(71.4)$ \\
\hline \multirow[t]{4}{*}{ Foundation year of infection management room of medical institution } & $2011 \sim 2015$ & $1(14.3)$ \\
\hline & $2006 \sim 2010$ & $3(42.9)$ \\
\hline & $2001 \sim 2005$ & $2(28.6)$ \\
\hline & $<2000$ & $1(14.3)$ \\
\hline \multirow{2}{*}{$\begin{array}{l}\text { Number of persons in infection management room of medical institutions } \\
\text { (not including the will of infection management) }\end{array}$} & 3 & $1(14.3)$ \\
\hline & 1 & $6(85.7)$ \\
\hline Occupation type of persons allocated in infection management room & nurse & $9(100.0)$ \\
\hline \multirow[t]{3}{*}{ Career period of working in infection management room } & $>5$ & $1(14.3)$ \\
\hline & $2 \sim 3$ & $2(28.6)$ \\
\hline & $<1$ & $4(57.1)$ \\
\hline \multirow[t]{2}{*}{ Handover when working at infection management room } & Yes & $6(85.7)$ \\
\hline & No & $1(14.3)$ \\
\hline
\end{tabular}

1 번이 1 개 기관(14.3\%)으로 조사되었다. 의료기관에서의 감염관 리지침(규정)의 유무는 말초정맥관리, 중심정맥관 관리, 유치도뇨 관 관리, 인공호흡기 관리, 기도 흡인관리, 의료기구 관리, 격리, 손 위생, 수술장 감염관리, 창상부위 감염관리, 내시경실 감염관리, 자 상사고 감염관리, 직원 감염관리, 환경관리, 오염세탁물 관리 15 개 분야 대해서 규정 및 지침의 보유 유무와각각의 수행 정도를 5점 척 도를 이용하여 분석 한 결과 7 개의 의료기관 중 15 개 항목에 대해 감염관리지침이 마련되어 있는 기관이 6개 기관(85.7\%)이며 1 개 기관(14.3\%)은 기도 흡인관리, 의료기구 관리, 창상부위 감염관리 를 제외한 12 개 항목에서 감염관리지침(규정)이 마련되어 있었다. 감염관리지침 15 개 항목 중 7 개 의료기관에서의 5 점 척도의 수행 도를 퍼센트로 환산했을 때 자상사고 감염관리(97.1\%), 내시경실 감염관리(91.4\%), 인공호흡기 관리(88.6\%), 오염세탁물 관리 (88.6\%), 격리(85.7\%), 직원 감염관리(85.7\%), 말초정맥관리 (82.9\%), 중심정맥관 관리(82.9\%), 유치도뇨관 관리(82.9\%), 수술 장 감염관리(82.9\%), 환경관리(77.1\%), 기도 흡인관리(74.3\%), 손 위생 관리(71.4\%), 의료기구관리(68.6\%), 창상부위 감염관리 (68.6\%) 순으로 조사되었다. 의료기관의 감염관리실에서 실제로 감염감시 활동을 하는데 제일 중요시하는 부분은 손위생 관리가 3 개 기관(42.9\%), 중환자실 관리가 2개 기관(28.6\%), 인공호흡기(폐 렴) 관리와 중심정맥관 관리가 각각 1 개 기관(14.3\%)으로 조사되 었다. 그리고 의료기관의 감염관리실 감염관리 활동에서 가장 힘든 부분에 대한 질문은 인력과 시간, 미생물 배양 판독, 감염관리에 대 한 비용, 감염통계 등 다양하게 조사되었으며 대부분의 의료기관에 서는 감염관리실 인력에 대한 부분이 가장 커다란 문제로 제기되었 다(Table 2, 3).
Table 2. Education frequency of Jeju-area infection management room

\begin{tabular}{lcc}
\hline Characteristics & Categories & $\mathrm{n}(\%)$ \\
\hline Frequency of in-house education for & $>4$ & $1(14.3)$ \\
employees in infection management & $3 \sim 4$ & $5(71.4)$ \\
room (per year) & $2 \sim 3$ & $1(14.3)$ \\
Frequency of external society edu- & $>4$ & $2(28.6)$ \\
cation for exclusive personnel of & $3 \sim 4$ & $2(28.6)$ \\
infection management room (per & $2 \sim 3$ & $2(28.6)$ \\
year) & 1 & $1(14.3)$ \\
\hline
\end{tabular}

제주지역 종합병원의 감염관리실 모두 감염관리지침을 비치하 고 있었으며, 새로운 감염 예방 및 감염관리 교육을 위한 전담직원 의 감염관리 교육빈도가 높게 나타났다. 7 개 기관 모두 간호사가 전 담직원으로 근무를 하고 있으며 미생물 관련 배양 판독, 다제내성 균의 출현빈도, 감염통계 등 미생물 검사에 대한 내용을 보고 받는 데 많은 부분 어려움을 있었으며 미생물 검사실 임상병리사의 도움 을 필요로 하였다.

\section{3. 임상병리사의 감염관리 역할}

감염병의 예방 및 관리에 관한 법률 제 2 조에 의한 지정 감염병 중 의료관련 감염병은 메티실린내성 황색포도알균(MRSA), 반코마이 신내성 황색포도알균(VRSA), 반코마이신내성 장알균(VRE), 다제 내성 녹농균(MRPA), 다제내성 아시네토바우마니균(MRAB), 카바 페넴내성 장내세균속균종(CRE) 6종으로 규정되었다. 이에 대한 병원감염 감시활동이 중요한 사회적 문제로 제기되었다. 이들에 대 한 정확한 진단결과가 필요하며 또한 감염관리실에 보다 빠르게 보 고되는 것이 병원감염관리에 효과적이다. 
Table 3. Infection management guideline and performance of Jeju-area infection management room

\begin{tabular}{|c|c|c|c|}
\hline Characteristics & $\begin{array}{c}\text { Has infection } \\
\text { management } \\
\text { guideline }\end{array}$ & n (\%) & $\begin{array}{c}\text { Performance } \\
(\%)\end{array}$ \\
\hline $\begin{array}{l}\text { Peripheral vein } \\
\text { management }\end{array}$ & $\begin{array}{l}\text { Yes } \\
\text { No }\end{array}$ & $\begin{array}{l}7(100.0) \\
0(0.0)\end{array}$ & 82.9 \\
\hline $\begin{array}{l}\text { Central vein } \\
\text { management }\end{array}$ & $\begin{array}{l}\text { Yes } \\
\text { No }\end{array}$ & $\begin{array}{l}7(100.0) \\
0(0.0)\end{array}$ & 82.9 \\
\hline $\begin{array}{l}\text { Indwelling urethra } \\
\text { management }\end{array}$ & $\begin{array}{l}\text { Yes } \\
\text { No }\end{array}$ & $\begin{array}{l}7(100.0) \\
0(0.0)\end{array}$ & 82.9 \\
\hline $\begin{array}{l}\text { Respirator } \\
\text { management }\end{array}$ & $\begin{array}{l}\text { Yes } \\
\text { No }\end{array}$ & $\begin{array}{l}7(100.0) \\
0(0.0)\end{array}$ & 88.6 \\
\hline $\begin{array}{l}\text { Tracheal suction } \\
\text { management }\end{array}$ & $\begin{array}{l}\text { Yes } \\
\text { No }\end{array}$ & $\begin{array}{l}6(85.7) \\
1(14.3)\end{array}$ & 74.3 \\
\hline $\begin{array}{l}\text { Medical tool } \\
\text { management }\end{array}$ & $\begin{array}{l}\text { Yes } \\
\text { No }\end{array}$ & $\begin{array}{l}6(85.7) \\
1(14.3)\end{array}$ & 68.6 \\
\hline $\begin{array}{l}\text { Isolation } \\
\text { management }\end{array}$ & $\begin{array}{l}\text { Yes } \\
\text { No }\end{array}$ & $\begin{array}{l}7(100.0) \\
0(0.0)\end{array}$ & 85.7 \\
\hline $\begin{array}{l}\text { Hand sanitation } \\
\text { management }\end{array}$ & $\begin{array}{l}\text { Yes } \\
\text { No }\end{array}$ & $\begin{array}{l}7(100.0) \\
0(0.0)\end{array}$ & 71.4 \\
\hline $\begin{array}{c}\text { Operation room } \\
\text { management }\end{array}$ & $\begin{array}{l}\text { Yes } \\
\text { No }\end{array}$ & $\begin{array}{ll}7 & (100.0) \\
0 & (0.0)\end{array}$ & 82.9 \\
\hline $\begin{array}{l}\text { Wound } \\
\text { management }\end{array}$ & $\begin{array}{l}\text { Yes } \\
\text { No }\end{array}$ & $\begin{array}{l}6(85.7) \\
1(14.3)\end{array}$ & 68.6 \\
\hline $\begin{array}{l}\text { Endoscope room } \\
\text { management }\end{array}$ & $\begin{array}{l}\text { Yes } \\
\text { No }\end{array}$ & $\begin{array}{ll}7 & (100.0) \\
0 & (0.0)\end{array}$ & 91.4 \\
\hline $\begin{array}{l}\text { Stab accident } \\
\text { management }\end{array}$ & $\begin{array}{l}\text { Yes } \\
\text { No }\end{array}$ & $\begin{array}{l}7(100.0) \\
0(0.0)\end{array}$ & 97.1 \\
\hline $\begin{array}{l}\text { Employee } \\
\text { management }\end{array}$ & $\begin{array}{l}\text { Yes } \\
\text { No }\end{array}$ & $\begin{array}{ll}7 & (100.0) \\
0 & (0.0)\end{array}$ & 85.7 \\
\hline $\begin{array}{l}\text { Environment } \\
\text { management }\end{array}$ & $\begin{array}{l}\text { Yes } \\
\text { No }\end{array}$ & $\begin{array}{l}7(100.0) \\
0(0.0)\end{array}$ & 77.1 \\
\hline $\begin{array}{l}\text { Infected laundry } \\
\text { management }\end{array}$ & $\begin{array}{l}\text { Yes } \\
\text { No }\end{array}$ & $\begin{array}{l}7(100.0) \\
0(0.0)\end{array}$ & 88.6 \\
\hline
\end{tabular}

제주지역 의료기관에서 6종의 다제내성균주에 대한 감염관리 활동 유무에 대한 질문에는 6종 모두 감염감시 활동을 하는 의료기 관은 1 개 기관(14.3\%)으로 조사되었으며, MRSA, VRE, MRAB, $\mathrm{CRE}$ 에 대해서만 감염감시 활동을 하는 의료기관은 1 개 기관 (14.3\%), MRSA, VRE, MRPA에 대해서만 감염감시 활동을 하는 의 료기관은 1 개 기관(14.3\%), 나머지 4개 기관은 MRSA, VRE에 대해 서만 감염감시 활동을 하는 것으로 조사되었다. 조사방법은 대부부 분의 의료기관에서 미생물실의 항생제 감수성 결과지 확인, 전산상 에서 결과지 확인, 업무보고 등으로 방법으로 조사하는 것으로 나 타났다. 감염관리실과 미생물검사실 임상병리사와의 상호 협조정 도 및 협조내용에 대한 질문에는 7개 의료기관 모두 감염관리실과 임상병리사의 상호협동 정도가 중 ·상으로 나타났으며, 협조 내용 으로는 미생물에 대한 결과 기록지 및 항생제 감수성검사 판독에 관한 내용이 주를 이루었으며, 감염관리실에서 업무 중에 진단검사 의학과에서 하는 일을 얼마나 자주 참관하며 인지도 정도에 대한
Table 4. Healthcare-associated infections surveillance

\begin{tabular}{ccl}
\hline Characteristics & Surveillance & n (\%) \\
\hline MRSA $^{*}$ & Yes & $7(100.0)$ \\
VRSA $^{\dagger}$ & No & $0(0.0)$ \\
& Yes & $1(14.3)$ \\
VRE $^{\ddagger}$ & No & $6(85.7)$ \\
& Yes & $7(100.0)$ \\
MRPA $^{\S}$ & No & $0(0.0)$ \\
MRAB $^{\|}$ & Yes & $2(28.6)$ \\
& No & $5(71.4)$ \\
CRE $^{\pi}$ & Yes & $2(28.6)$ \\
& No & $5(71.4)$ \\
& Yes & $2(28.6)$ \\
& No & $5(71.4)$ \\
\hline
\end{tabular}

*MRSA, Methicillin Resistant Staphylococcus aureus; 'VRSA, Vancomycin Resistant Staphylococcus aureus; ${ }^{\dagger}$ VRE, Vancomycin Resistant Enterococci; ${ }^{\S}$ MRPA, Multi-drug Resistant Pseudomonas aeruginosa; "MSAB, Multi-drug Resistant Acinetobacter baumannii;, ${ }^{\pi}$ CRE, Carbapenem Resistant Enterobacteriaceae

질문에는 대부분의 의료기관에서 관심도는 높지만 실제적으로는 거의 참관하지 못하거나 인지하지 못하는 것으로 조사되었다. 감염 관리실의 검사업무의 흐름에 대한 부분에서 임상병리사 역할에 대 한 질문에는 혈액매개 관련 질병, 법정감염병의 신고에 관한 업무, 특별관리 배양균주에 관한 업무, 환경배양, 직원감염, 다제내성균 주 등에 대한 업무의 협조가 필요하다고 조사되었다(Table 4).

\section{고 찰}

최근 보건복지부는 병원 감염관리실 설치 대상을 단계적으로 확 대하고 감염관리 인력을 확충하겠다고 밝혔으며, 현재는 감염관리 실 설치 대상은 중환자실이 있는 200 병상 이상 병원급 의료기관에 서 중환자실이 없는 200 병상 이상 병원으로 확대한 후 병상 기준도 200 병상에서 150 병상으로 조정할 계획과 현실에 맞게 감염관리 시스템을 개선하고 관련 인력을 확충하기 위한 의료법 법안 개정을 추진 중이다. 감염관리 전담 인력과 관련된 시행규칙 중 세 번째인 '감염관리에 경험과 지식이 있는 사람으로서 해당 의료기관의 장이 인정하는 사람'이라는 규정이 좀 더 구체적일 필요성이 있다. 현재 대한임상병리사협회는 병원 감염관리실 인력에 임상병리사가 포 함되어야 하는 당위성을 주장하고 있다. 임상병리사들은 일상적으 로 병원 현장에서 상시 감염관리 업무를 담당해오고 있으며, 세균 을 분리 배양하고 동정하며 세균에 대한 항균제 감수성 검사를 실 시하고 있어 세균의 내성특성, 균 서식처의 특징을 분석하여 정보 를 빠르게 감염관리실에 제공하여 이에 대한 대처를 빠르게 진행 할 수 있다. 이러한 업무는 의사, 간호사 업무와 구분되는 전문적인 영역이라 할 수 있다. 임상병리사들의 감염관리분야에서의 역할 제 
고를 위해 2014년 대한감염관리임상병리사회를 창립하여 감염관 리 핵심 전문인력으로서 감염관리 실무자 양성(기초, 심화교육), 감 염관리검사 표준 지침서 개발 및 멀티미디어 제작, 감시검사 수가 법제화 노력, 감염관리 임상병리사 전국 실태조사, 전문가 역량 수 준 향상을 전제로 유관단체와 공동연구 진행, 감염관리학 석, 박사 배출 등 업무를 담당하고 있다.

다제내성균주를 중재하는 다양한 관리 방법들의 효과 및 효율성 에 대해서는 논란의 여지가 많으며 각 병원의 실정에 맞는 감염관 리 프로그램을 선택하여 운영하는 것이 필요하다[14]. 다제내성균 전파를 예방하기 위해 환자의 격리가 중요한데, 환자를 코호트하거 나, 의료진을 코호트하거나 심지어 병동을 폐쇄하는 조치가 도움이 되는 것으로 알려져 있다[15]. Park 등[16]의 연구에 의하면 국내 102 개의 종합병원을 대상으로 시행한 실태조사에서 항균제 내성 균 감염관리에서 가장 문제가 되는 항목이 격리병실 비용문제라고 답하거나 $(37 \%)$, 격리장소 부적절 또는 부족문제라고 답하여(31\%) 일반병실에서의 격리병상 운영이 어려움을 호소하였다고 보고하 였으며, Yang[17]의 연구에서 VRE 균주의 유행과 전파를 막기 위 한 감염관리지침이 있으나 모든 병원에서 적용하기가 어려운 실정 이고 다각적 감염관리를 시행하여도 근절하기 힘든 병원감염의 주 요 다제내성균이라고 보고하였다.

본 연구에 의하면 제주도내 위치한 종합병원 7개 기관은 모두 감 염관리실을 운영하고 있으며, 1 개 기관을 제외하고는 감염관리실 에 1 인의 간호사가 배치되어 있으며 1 개 기관에만 3 명의 간호사가 전담인력으로 업무를 담당하고 있다. 전담인력의 외부학회 등에서 의 감염관리 교육빈도는 $3 \sim 4$ 번이었으며, 직원대상 자체 의료기관 의 교육은 1 년에 3 번 정도 하는 것으로 조사되었다. 의료기관에서 의 15 개 분야에 대한 감염관리지침(규정)은 7 개 의료기관이 모두 보유하고 있었으며 각각의 수행 정도를 조사 한 결과 자상사고 감 염관리(97.1\%), 내시경실 감염관리(91.4\%), 인공호흡기 관리 (88.6\%) 순으로 조사되었고, 의료관련 감염병은 MRSA, VRE 감염 감시 활동은 7개 의료기관 모두 하고 있었으며, VRSA, MRPA, $\mathrm{MRAB}, \mathrm{CRE}$ 를 포함하여 6종 모두 감염감시 활동을 하는 의료기관 은 1 개 기관으로 조사되었다. 의료관련 감염병에 대한 조사방법은 미생물실의 항생제 감수성 검사 결과지와 업무보고 등의 방법으로 조사하는 것으로 나타났으며, 진단검사의학과 임상병리사와의 협 조내용은 주로 미생물에 대한 결과 기록지 및 항생제 감수성 검사 판독에 관한 내용이었다. 감염관리실에서 임상병리사 역할에 대한 질문에는 혈액매개 관련 질병, 법정감염병의 신고에 관한 업무, 특 별관리 배양균주에 관한 업무, 환경배양, 직원감염, 다제내성균주 등에 대한 업무의 협조가 있어야 한다는 자료를 얻을 수 있었다. Jeong 등[18]의 연구에 의하면 134개 의료기관을 대상으로 국내
의료기관의 의료관련감염 관리 실태를 조사한 결과 $99.3 \%$ 의 의료 기관이 감염관리위원회를 설치하였고 평균 개최 횟수는 연 3.4회 였으며, 감염관리실무자가 1 명 배치된 곳이 $54.5 \%$, 전담근무가 $62.7 \%$ 이었다. 실무자의 $95.5 \%$ 가 간호사로 평균 37.2 세, $48.9 \%$ 가 석사이상, 평균 병원 경력은 13.5 년, 감염관리실무 경력은 3.2 년이 었으며 $30.8 \%$ 가 1년 미만이었다. 감염감시는 $100 \%$, 개선활동은 $75.4 \%$ 의 의료기관에서 수행하는 것으로 보고하였다. 본 연구의 설 문도구는 Kang [19]의 구조화된 설문도구와는 다르지만 의료기관 이 일반적 특성, 의료기관의 감염관리위원회 운영현황, 의료기관 감염관리실 운영 및 인력 현황, 의료기관 의료관련감염 관리 활동 현황 파악 등으로 구성된 설문지로 구체적인 목적은 동일하다고 할 수 있다. 본 연구의 설문도구는 앞에서 의료기관의 병원감염관리 현황과 더불어 감염관리실에서의 애로사항을 파악하고자 했으며 임상병리사의 역할과의 연관성에 대해서 설문조사를 하였다.

본 연구결과 제주지역 의료기관의 감염관리는 모든 기관이 감염 관리실을 운영하고 전담인력을 구성하고 병원감염관리지침을 보 유하고 수행하는 우수한 점을 보였지만, 대부분의 기관이 간호사 1 인 구성의 감염관리실을 운영하여 전담인력 확보 및 미생물 관련 배양 판독, 다제내성균의 출현빈도, 감염통계 등 미생물 검사에 대 한 내용을 보고 받는데 많은 부분 어려움을 호소하였다. 이에 감염 관리의 실질적인 업무를 담당할 수 있는 임상병리사가 의료법 시행 규칙에 있는 감염관리에 경험과 지식이 있는 사람으로 충분한 자질 과 경험이 있다고 생각되며 감염관리실을 운영함에 있어 감염관리 간호사(Infection Control Nurse, ICN)와 미생물에 전문적인 지식 을 갖춘 임상병리사(감염관리임상병리사; Infection Control Medical Technologist, ICMT; Infection Control Microbiological Technologist, ICMT)가 전담자로서 업무를 수행한다면 지금보다 더욱 발전된 감염관리실 운영이 될 것으로 보인다. 향후 감염관리 의 정착화를 위해서는 전국적으로 종합병원을 비롯한 취약한 중소 병원의 감염관리에 대한 전폭적 지원과 감염관리 전문 의료시스템 도입이 중요한 과제라 사료된다.

\section{요 약}

제주지역 종합병원 감염관리 현황을 조사하여, 병원감염관리 실 태와 문제점을 파악하고자 하였으며 감염관리의 중요성을 인식시 키고 감염관리 실무자로서 임상병리사의 역할 방안을 모색하기 위 하여 제주특별자치도 제주시와 서귀포시에 위치한 종합병원 7개 기관을 대상으로 감염관리 현황을 설문지를 통하여 조사하였다. 제 주지역 의료기관의 감염관리는 모든 기관이 감염관리실을 운영하 고 전담인력을 구성하고 병원감염관리지침을 보유하고 수행하는 
우수한 점을 보였지만, 대부분의 기관이 간호사 1 인 구성의 감염관 리실을 운영하여 전담인력 확보 및 미생물 관련 배양 판독, 다제내 성균의 출현빈도, 감염통계 등 미생물 검사에 대한 내용을 보고 받 는데 많은 부분 어려움을 호소하였다. 이에 감염관리의 실질적인 업무를 담당할 수 있는 임상병리사가 의료법 시행규칙에 있는 감염 관리에 경험과 지식이 있는 사람으로 충분한 자질과 경험이 있다고 생각되며 감염관리실을 운영함에 있어 감염관리간호사와 미생물 에 전문적인 지식을 갖춘 임상병리사(감염관리임상병리사)가 전담 자로서 업무를 수행한다면 지금보다 더욱 발전된 감염관리실 운영 이 될 것으로 보이며, 향후 감염관리를 제대로 하기 위해서는 전국 적으로 종합병원을 비롯한 취약한 중소병원의 감염관리에 대한 전 폭적 지원과 감염관리 전문 의료시스템 도입이 중요한 과제라 사료 된다.

\section{Acknowledgements: None \\ Funding: None \\ Conflict of interest: None}

\section{References}

1. CDC. CDC/NHSN Surveillance definitions for specific types of infections [internet]. USA: Center for Disease Control and Prevention; 2014 [cited 2016 March 21]. Available from: http://www.cdc.gov/nhsn/pdfs/pscmanual/17pscnosinfdef_current.pdf.

2. CDC. Antibiotic resistance threats in the United States, 2013 [internet]. USA: Center for Disease Control and Prevention; 2014 [cited 2016 March 21]. Available from: http://www. cdc.gov/drugresistance/threat-report-2013/pdf/ar-threats2013-508.pdf.

3. Yun KO, Kim HY. A study regarding bacterial contamination of surfaces in dental offices. Korean J Clin Lab Sci. 2015; 47:279-285.

4. Lee JK. Hospital infection control system improvement Hospital infection control system enhanced. Research Institute for Healthcare Policy Korean Medical Association. 2015; 13:155-158.

5. Kim Y. Hospital infection control system improvement Hospital and health care utilization culture for infection control. Research Institute for Healthcare Policy Korean Medical Association. 2015;13:159-161.

6. Oh HS, Chung HW, Kim JS, Cho SI. National survey of the status of infection surveillance and control programs in acute care hospitals with more than 300 beds in the Republic of Korea. Am J Infect Control. 2006;34:223-233.

7. Jeong JS, Yoon SW, Park ES, Kim KM, Yoo SY, Jeong IS, et al. The present situation of infection control professionals, organization, and activities in Korean acute care general hospitals. Korean Journal of Nosocomial Infection Control. 2006;11: 58-69.

8. Kim YA, Lee HM, Lee KW. Contamination of the hospital environmental by pathogenic bacteria and infection control. Korean J Nosocomial Infect Control. 2015; 20:1-6.

9. Korean society for nosocomial infection control [KOSNIC]. Infection control and prevention in healthcare facilities. 4th ed. Seoul: Hanmi medical publishing company; 2011. p3-8.

10. The Steering Committee of the Korean Nosocomial Infections Surveillance System. Korean Nosocomial Infections Surveillance System (KONIS) report: data summary from July 2013 through June 2014[Internet]. Chungcheongbuk-do: The Korean Nosocomial Infections Surveillance System; 2014 [cited 2016 March 21]. Available from: http://konis.cdc.go.kr/konis/sub/reports_ icu.htm.

11. Barsanti MC, Woeltje KF. Infection prevention in the intensive care unit. Infectious Disease Clinics of North America. 2009;23:703-725.

12. Cosgrove SE. The relationship between antimicrobial resistance and patient outcomes: mortality, length of hospital stay, and health care costs. Clinical Infectious Diseases. 2006;42(2): 82-89.

13. Kim KM, Kim HJ. Nationwide survey on the current status of infection control in oriental medical hospital. Korean J Nosocomial Infect Control. 2011;16:63-69.

14. Choi JS, Kim MR, Kim YH, Huh AJ, Kim KS. Analysis of the effectiveness in the hospital management of methicillin-resistant Staphylococcus aureus by different isolation policies. Korean J Nosocomial Infect Control. 2005;10:73-77.

15. Siegel JD, Rhinehart E, Jackson M, Chiarello L. The Healthcare Infection Control Practices Advisory Committee. Management of multidrug-resistant organisms in healthcare settings. Am J Infect Control. 2007;35(Suppl):S165-193.

16. Park YJ, Jeong JS, Park ES, Shin ES, Kim SH, Lee YS. Survey on the infection control of multidrug-resistant microorganisms in general hospitals in Korea. Korean J Nosocomial Infect Control. 2007;12:112-121.

17. Yang BS. Rapid detection of vancomycin-resistance Enterococci by SYBR green real-time PCR. Korean J Clin Lab Sci. 2014; $46: 64-67$.

18. Jeong SY, Kim OS, Lee JY. The status of healthcare-associated infection control among healthcare facilities in Korea. Journal of Digital Convergence. 2014;12(5):353-366.

19. Kang MW. National survey and development of standardized practice on the infection control in Korea. Seoul: Ministry of Health and welfare; 2004. p101-118. 